\title{
MENINGKATKAN HASIL BELAJAR SISWA PADA MATA PELAJARAN IPA DENGAN MENGGUNAKAN METODE EKSPERIMEN DI KELAS V SD NEGERI 101823 BEKALA
}

\author{
Hotma Tiolina Siregar \\ Surel : tiolinahotma@gmail.com
}

\begin{abstract}
The researcher aims to know the suitability of the action with the plan that has been prepared to know the extent to which the implementation of the action can produce changes in accordance with the desired. The instrument used is the test description and the observation sheet. This research is a classroom action research (PTK) using Experimental method on science subjects. Research subjects in class V SD Negeri 101823 Bekala which amounted to 25 people. Implementation of learning by using the experimental method on the subject of Magnet Style goes well. This is seen from the results of teacher observation and student activity, with the details of the observation of teacher activity cycle I is $63,5 \%$ that categorized enough into the second cycle is $76 \%$ both categorized and student observations on the first cycle is $62 \%$ that categorized enough and cycle II ie $74 \%$ are categorized well. Student learning outcomes after using the experimental learning method on the subject Magnet Style has increased.
\end{abstract}

Key Words: Learning Outcomes, Experimental Methods

\section{PENDAHULUAN}

Pendidikan adalah salah satu bentuk perwujudan kebudayaan manusia yang dinamis dan sarat akan perkembangan. Oleh karena itu perubahan dan perkembangan pendidikan adalah hal yang memang seharusnya terjadi sejalan dengan perubahan budaya kehidupan. Pendidikan yang mampu mendukung pembangunan di masa mendatang adalah pendidikan yang mampu mengembangkan potensi peserta didik, sehingga yang bersangkutan mampu menghadapi dan memecahkan problema kehidupan yang dihadapinya.

Menurut undang-undang No.20 tahun 2003 bab II pasal 3, menjelaskan tentang fungsi dan tujuan pendidikan nasional yaitu pendidikan nasional berfungsi untuk mengembangkan kemampuan dan membentuk watak serta peradaban bangsa yang bermartabat, bertujuan untuk berkembangnya potensi peserta didik agar menjadi manusia yang beriman dan bertaqwa kepada tuhan Yang Maha Esa, berakhlak mulia, sehat, berilmu, mandiri dan menjadi warga negara yang demokratis sertabertanggung jawab.

Untuk mewujudkan pendidikan yang baik dan untuk mencapai belajar yang maksimal harus didukung oleh beberapa unsur pendidikan, salah satunya adalah seorang guru. Guru merupakan unsur terpenting dalam pendidikan. Pembelajaran akan lebih menyenangkan jika guru mampu menciptakan pembelajaran 

yang kondusif.

Ilmu pengetahuan alam (IPA) adalah ilmu pengetahuan alam yang sistematis dan dirumuskan, yang berhubungan dengan gejala-gejala kebendaan dan didasarkan terutama atas pengamatan dan deduksi.

Kita ketahui tujuan pembelajaran ipa di sekolah dasar untuk mengembangkan rasa ingin tahu dan suatu sikap positif terhadap sains, teknologi dan masyarakat, mengembangkan keterampilan proses untuk menyelidiki alam sekitar, memecahkan masalah dan membuat keputusan dan ikut serta dalam memelihara, menjaga dan melestarikan lingkungan alam. Oleh karena itu pembelajaran IPA sangat penting diajarkan di sekolah dasar.

Pada SDN Nomor 101823 Bekala, pembelajaran IPA masih belum tercapai secara maksimal hal ini disebabkan Guru hanya menggunakan metode ceramah, Metode yang digunakan guru kurang menarik perhatian siswa, pola berpikir siswa kurang berkembang hanya terpaku pada materi dan hapalan bukan pemahaman berdasarkan pikiran. Dengan demikian guru perlu mengubah cara mengajarnya dengan metode ataupun strategi pembelajaran sehingga suasan pembelajaran dapat dirancang dengan penuh kreaktivitas, sehingga siswa dapat diharapkan menjadi Aktif. Dari uraian diatas penulis berkeinginan melakukan penelitian dengan judul : Meningkatkan Hasil Belajar Siswa pada Mata Pelajaran IPA dengan Menggunakan Metode
Eksperimen di Kelas V SD Negeri 101823 Berkala Tahun Ajaran 2016/2017.

Dari latar belakang masalah yang telah diuraikan, maka dapat diidentifikasi beberapa masalah yang ditemui pada pelaksanaan pembelajaran IPA di Kelas V yaitu :
a. Guru hanya menggunakan metode ceramah
b. Metode yang digunakan guru kurang menarik perhatian siswa
c. Pola berpikir siswa kurang berkembang hanya terpaku pada materi dan hapalan bukan pemahaman berdasarkan pikiran.

Berdasarkan identifikasi masalah di atas, maka peneliti membatasi masalah pada :

a. Penggunaan Metode Eksperimen

b. Mata pelajaran IPA dengan materi Gaya Magnet di kelas V SD Negeri 101823 Bekala Tahun Ajaran 2016/2017”.

Berdasarkan identifikasi dan batasan masalah yang telah diuraikan diatas, maka yang menjadi rumusan masalah dalam penelitian ini adalah :

a. Bagaimanakah pelaksanaan pembelajaran dengan menggunakan metode Eksperimen untuk mata pelajaran IPA dengan materi Gaya Magnet di kelas V SD Negeri 101823 Bekala Tahun Ajaran 2016/2017?

b. Apakah hasil belajar siswa meningkat pada mata pelajaran IPA dengan materi Gaya Magnet dengan menggunakan Metode 
Hotma Tiolina Siregar : Meningkatkan Hasil ....

Eksperimen di kelas V SD

Negeri 101823 Bekala Tahun

Ajaran 2016/2017?

\section{METODE PENELITIAN}

Penelitian ini dilaksanakan di SD Negeri 101823 Bekala Kecamatan Pancur Batu Tahun Ajaran 2016/2017. Subjek dalam penelitian ini adalah siswa-siswi kelas V SD Negeri 101823 Bekala yang berjumlah 25 orang, laki-laki 11 orang dan perempuan 14 orang pada Tahun Ajaran 2016/2017. Objek penelitian adalah Penggunaan metode Eksperimen pada mata pelajaran IPA dengan materi Gaya Magnet.

Penelitian ini dilaksanakan untuk memperbaiki proses pembelajaran yang bertujuan untuk meningkatkan kemampuan berfikir dan hasil belajar siswa dengan menggunakan metode Eksperimen pada mata pelajaraan IPA pada pokok bahasan Gaya Magnet di kelas V SD Negeri 101823 Bekala. Prosedur Penelitian Tindakan Kelas (PTK) biasanya meliputi beberapa siklus. Siklus tersebut terdiri dari 4 komponen, yaitu: 1) Perencanaan 2) Tindakan 3) Observasi 4) Refleksi.

Alat yang digunakan dalam mengumpulkan data pada penelitian ini adalah tes dan observasi.

Sesuai dengan tujuan penelitian, maka analisis data yang dilakukan seperti berikut

a. Penilaian Aktivitas Guru

Teknik analisis data pada penilaian lembar observasi guru adalah seperti dijelaskan Piet A.
Sahertien (2013:61) setelah pengamat/_ pemilik sekolah/kepala sekolah mengadakan observasi terhadap suatu proses belajar -mengajar maka pengamat mengisi kolomkolom A, B, C, D, E dengan tanda (V) sesuai dengan kenyataan hasil observasi.

Kriteria yang digunakan adalah menentukan nilai presentasi yang diklasifikasikan atas dasar tingkat sebagai berikut :

$H P=\frac{\text { jumlah skor hasil observasi }}{\text { Jumlah pernyataan }}$

b. Penilaian Aktivitas Siswa.

Analisis data yang digunakan pada lembar observasi adalah menggunakan format penilaian sikap (selama proses pembelajaran) yang dijelaskan Asep Jihad dan Abdul Haris (2012:130-131) yaitu:

NilaiSiswa $=\frac{\text { Skor Perolehan }}{\text { Skor Maksimum }} \times 100$

c. Hasil Belajar Siswa. Hasil belajar dapat dilihat dari ketuntasan belajar siswa secara individu, klasikal serta rata-rata hasil belajar yang diuraikan sebagai berikut : Seorang siswa dikatakan tuntas belajar jika proporsi jawaban benar siswa $70 \%$. Dapat dihitung dengan menggunakan rumus 
$\mathrm{KB}=\frac{T}{T t} \mathrm{x} 100 \%$

(Trianto, 2016:241)

Keterangan :

KB : Ketuntasan belajar

$\mathrm{T}$ : Jumlah skor yang diperoleh siswa

Tt: Skor total

Untuk menganalisis persentase ketuntasan belajar secara klasikal dirumuskan sebagai berikut :

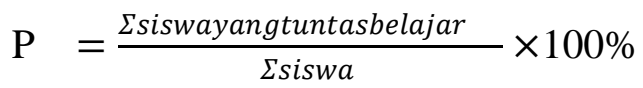
Zainal Aqib (2011:41)

Keterangan :

P : ketuntasan klasikal Suatu kelas dikatakan tuntas belajar bila di kelas tersebut terdapat $85 \%$ yang telah mencapai daya serap lebih dari atau sama dengan $70 \%$.

d. Dalam mencari peningkatan belajar siswa, digunakan rumus rata-rata yaitu :

$$
\bar{X}=\frac{\sum f_{i} x_{i}}{\sum f_{i}}
$$

(Sudjana, 2015: 70)

Keterangan :

$\bar{X}=$ Nilai Rata-rata

$x_{i}=$ tanda kelas interval

$f_{i}=$ frekuensi yang sesuai dengan tanda kelas $x_{i}$

\section{HASIL PENELITIAN DAN PEMBAHASAN}

Dengan menggunakan metode pembelajaran Eksperimen pada pokok bahasan Gaya Magnet pada awal pelaksanaan penelitian tindakan kelas sampai dengan selesainya tindakan pengajaran yang dilakukan. Hasil Observasi yang diperoleh dari proses pembelajaran aktivitas guru dapat di lihat pada Tabel berikut ini :

\section{Tabel Hasil Observasi Aktivitas Guru Siklus I}

\begin{tabular}{|l|l|l|}
\hline No & Aspek Yang Diobservasi & Penilaian \\
\hline 1 & Keterampilan membuka pembelajaran & 70 \\
\hline 2 & Menyampaikan materi dan tujuan pembelajaran & 65 \\
\hline 3 & Memberikan penjelasan dengan bahasa yang jelas & 60 \\
\hline 4 & \begin{tabular}{l} 
Penguasaan kelas \\
\hline 5
\end{tabular} & $\begin{array}{l}\text { Melaksanakan proses pembelajaran secara sistematik dengan } \\
\text { urutan rpp }\end{array}$ \\
\hline 6 & $\begin{array}{l}\text { Menguraikan metode pembelajaran sesuai dengan cara kerja } \\
\text { metode Eksperimen dalam kegiatan inti pembelajaran }\end{array}$ & 61 \\
\hline
\end{tabular}


Hotma Tiolina Siregar : Meningkatkan Hasil ....

\begin{tabular}{|l|l|l|}
\hline 7 & Memotivasi siswa untuk aktif bertanya & 60 \\
\hline 8 & Penggunaan alokasi waktu sesuai dengan rpp & 65 \\
\hline 9 & Memberikan penilaian & 70 \\
\hline 10 & Mengadakan evaluasi & 61 \\
\hline Jumlah & 635 \\
\hline Persentase & $63,5 \%$ \\
\hline Kategori & Cukup \\
\hline
\end{tabular}

Dapat digunakan dengan rumus :

$$
\begin{aligned}
\mathrm{HP} & =\frac{\text { Jumla } h \text { skor Observasi }}{\text { Jumla } h \text { Butir pernyata an }} \\
\mathrm{HP} & =\frac{635}{10} \\
& =63,5
\end{aligned}
$$

Dari setiap aspek yang diamati untuk kegiatan aktivitas guru pada siklus I memiliki jumlah 635 dengan nilai yang diperoleh mencapai $63,5 \%$ dapat dinyatakan aktivitas guru pada proses pembelajaran dengan menggunakan metode pembelajaran Eksperimen pada mata pelajaran IPA pokok bahasan Gaya Magnet di kelas V SD Negeri 101823 Bekala Tahun Ajaran 2016/2017 dapat dikategorikan cukup.
Selama proses pembelajaran guru (obsrver) juga mengamati aktivitas yang dilakukan siswa selama proses pembelajaran berlangsung khususnya keaktifan siswa dalam menggunakan metode pembelajaran Eksperimen yang telah dipersiapkan sebelumnya oleh peneliti. Hasil Observasi yang diperoleh dari proses pembelajaran aktivitas siswa dengan menggunakan metode pembelajaran Eksperimen pada siklus I dapat di lihat pada Tabel berikut ini :

Tabel Hasil Observasi Aktivitas Siswa Siklus I

\begin{tabular}{|l|l|l|}
\hline No & Aspek yang diobservasi & Penilaian \\
\hline 1. & Kesiapan menerima pembelajaran & 4 \\
\hline 2. & Mendengarkan penjelasan guru dengan baik & 3 \\
\hline 3. & Memperhatikan dan mencatat penjelasan guru & 4 \\
\hline 4. & Melakukan Eksperimen & 3 \\
\hline 5. & Keaktifan dalam kerja sama dengan kelompok & 2 \\
\hline
\end{tabular}




\begin{tabular}{|l|l|l|}
\hline 6. & Keaktifan dalam melakukan percobaan & 3 \\
\hline 7. & $\begin{array}{l}\text { Partisipasi dalam mengikuti arahan yang } \\
\text { diberikan oleh guru }\end{array}$ & 3 \\
\hline 8. & Keberanian dalam memberikan pendapat & 3 \\
\hline 9. & Membuat kesimpulan & 3 \\
\hline 10. & Aktif dalam pengerjaan test, tugas,LKS & 3 \\
\hline Jumlah & 31 \\
\hline Persentase & $62 \%$ \\
\hline Kategori & Cukup \\
\hline
\end{tabular}

\section{Rumus:}

Nilai $=\frac{\text { Skor yang diperoleh }}{\text { Jumlah SkorMaksimum }} \times 100$

$=\frac{31}{50} \times 100$

$=62$

Dari setiap aspek yang diamati untuk aktivitas kegiatan siswa pada siklus I diperoleh jumlah sebanyak 31 dengan nilai yang diperoleh mencapai $62 \%$ berdasarkan kriteria penilaian hasil observasi aktivitas siswa pada proses pembelajaran dengan menggunakan metode pembelajaran Eksperimen pada mata pelajaran IPA pokok bahasan Gaya Magnet di kelas V SD
Negeri 101823 Bekala Tahun Ajaran 2016/2017 dapat dikategorikan cukup. Ketuntasan hasil belajar siswa secara individu pada siklus I.

Berdasarkan tahap penelitian tindakan kelas maka diperoleh hasil belajar siswa pada pokok bahasan Gaya Magnet dengan menggunakan metode Eksperimen di peroleh hasil belajar siswa dapat dilihat pada tabel berikut ini :

Tabel Ketuntasan Hasil Belajar Siswa secara individu Siklus I

\begin{tabular}{|l|l|l|l|l|l|l|}
\hline No & Nama & $\begin{array}{l}\text { Skor } \\
\text { Perolehan } \\
(\mathbf{T})\end{array}$ & $\begin{array}{l}\text { Skor } \\
\text { Total } \\
\mathbf{( T t )}\end{array}$ & $\begin{array}{l}\text { Nilai } \\
\text { Akhir }\end{array}$ & KKM & $\begin{array}{l}\text { Keterangan } \\
\text { (Tuntas/Tidak } \\
\text { Tuntas) }\end{array}$ \\
\hline 1 & Agnes & 55 & 100 & 55 & 70 & Tidak Tuntas \\
\hline 2 & Amelia & 70 & 100 & 70 & 70 & Tuntas \\
\hline 3 & Ayu & 55 & 100 & 55 & 70 & Tidak Tuntas \\
\hline 4 & Brema & 70 & 100 & 70 & 70 & Tuntas \\
\hline 5 & Dewita & 70 & 100 & 70 & 70 & Tuntas \\
\hline 6 & Ibnu & 60 & 100 & 60 & 70 & Tidak Tuntas \\
\hline 7 & Intan & 75 & 100 & 75 & 70 & Tuntas \\
\hline 8 & Johan & 50 & 100 & 50 & 70 & Tidak Tuntas \\
\hline
\end{tabular}


Hotma Tiolina Siregar : Meningkatkan Hasil ....

\begin{tabular}{|l|l|l|l|l|l|l|}
9 & Juwanda & 70 & 100 & 70 & 70 & Tuntas \\
\hline 10 & Krisna & 85 & 100 & 85 & 70 & Tuntas \\
\hline 11 & M.Sabri & 70 & 100 & 70 & 70 & Tuntas \\
\hline 12 & M.Yoga & 75 & 100 & 75 & 70 & Tuntas \\
\hline 13 & Marsyanda & 45 & 100 & 45 & 70 & Tidak Tuntas \\
\hline 14 & Maymora & 70 & 100 & 70 & 70 & Tuntas \\
\hline 15 & Mikael & 60 & 100 & 60 & 70 & Tidak Tuntas \\
\hline 16 & Reza & 70 & 100 & 70 & 70 & Tuntas \\
\hline 17 & Riska & 60 & 100 & 60 & 70 & Tidak Tuntas \\
\hline 18 & Rizki & 85 & 100 & 85 & 70 & Tuntas \\
\hline 19 & Sandrina & 40 & 100 & 40 & 70 & Tidak Tuntas \\
\hline 20 & Sarah & 75 & 100 & 75 & 70 & Tuntas \\
\hline 21 & Sari & 70 & 100 & 70 & 70 & Tuntas \\
\hline 22 & Selpia & 85 & 100 & 85 & 70 & Tuntas \\
\hline 23 & Tegar & 60 & 100 & 60 & 70 & Tidak Tuntas \\
\hline 24 & Tika & 75 & 100 & 75 & 70 & Tuntas \\
\hline 25 & Yelen & 70 & 100 & 70 & 70 & Tuntas \\
\hline
\end{tabular}

Ketuntasan belajar siswa secara individu ditentukan dengan menggunakan rumus:

$K B=\frac{T}{T t} \times 100 \%$

Keterangan:

$\mathrm{KB}=$ ketuntasan belajar

$\mathrm{T}=$ jumlah skor yang diperoleh siswa

$\mathrm{Tt} \quad=$ jumlah skor total

Berdasarkan tabel di atas dapat dilihat dari 25 jumlah siswa kelas $\mathrm{V}$ maka yang tuntas secara individu pada siklus I sebanyak 16 orang siswa yang tuntas hasil belajarnya dan 9 orang siswa yang tidak tuntas hasil belajarnya. Siswa yang dikatakan tuntas secara individu apabila siswa tersebut mencapai nilai KKM yaitu 70. Dari hasil yang diperoleh masih banyak siswa yang belum tuntas secara individu. Ketuntasan hasil belajar siswa secara klasikal siklus I.

Berdasarkan data ketuntasan hasil belajar siswa secara klasikal belum tercapai maka dapat dilihat dari nilai individual siswa pada siklus I. Nilai ketuntasan klasikal pada siklus I dapat dilihat pada tabel berikut ini : 
SEJ VOLUME 7 NO. 1 JUNI 2017

Tabel Ketuntasan hasil Belajar Siswa Secara Klasikal Siklus I

\begin{tabular}{|l|l|l|l|}
\hline Ketuntasan & \multicolumn{2}{|l|}{ Siklus I } & Keterangan \\
\cline { 2 - 3 } & $\begin{array}{l}\text { Jumlah } \\
\text { siswa }\end{array}$ & Persentase & \\
\hline $\begin{array}{l}\text { Siswa yang tuntas } \\
\text { belajar }\end{array}$ & 16 & $64 \%$ & $\begin{array}{l}\text { Belum tuntas } \\
\text { secara klasikal }\end{array}$ \\
\hline $\begin{array}{l}\text { Siswa yang tidak } \\
\text { tuntas belajar }\end{array}$ & 9 & $36 \%$ & \\
\hline Jumlah siswa & 25 & $100 \%$ & \\
\hline
\end{tabular}

Untuk menghitung ketuntasan belajar siswa secara klasikal menggunakan rumus sebagai berikut:

$$
\begin{aligned}
\text { Ketuntasan Belajar } & =\frac{\sum \text { siswa yang tuntas belajar }}{\sum \text { siswa }} \times 100 \% \\
& =\frac{16}{25} \times 100 \\
& =64 \% \text { (Siswa yang tuntas) }
\end{aligned}
$$

Sedangkan persentase siswa yang tidak tuntas dapat ditentukan dengan menggunakan rumus sebagai berikut:

$$
\begin{aligned}
\text { Ketuntasan Belajar } & =\frac{\sum \text { siswa yang belum tuntas belajar }}{\sum \text { siswa }} \times 100 \% \\
& =\frac{9}{25} \times 100 \\
& =36 \% \text { (Siswa yang belum tuntas) }
\end{aligned}
$$

Tabel distribusi frekuensi hasil belajar IPA siswa siklus I

\begin{tabular}{|l|l|l|l|l|}
\hline No & Kelas Interval & \multicolumn{1}{|c|}{$\boldsymbol{f}_{\boldsymbol{i}}$} & \multicolumn{1}{|c|}{$\boldsymbol{x}_{\boldsymbol{i}}$} & \multicolumn{1}{c|}{$\boldsymbol{f}_{\boldsymbol{i}} \boldsymbol{x}_{\boldsymbol{i}}$} \\
\hline 1. & $40-47$ & 2 & 43,5 & 87 \\
\hline 2. & $48-55$ & 3 & 51,5 & 154,5 \\
\hline 3. & $56-63$ & 4 & 59,5 & 238 \\
\hline 4. & $64-71$ & 9 & 67,5 & 607,5 \\
\hline 5. & $72-79$ & 4 & 75,5 & 302 \\
\hline 6. & $80-87$ & 3 & 83,5 & 250,5 \\
\hline
\end{tabular}


Hotma Tiolina Siregar : Meningkatkan Hasil ....

\begin{tabular}{|l|l|l|l|}
\hline Jumlah & 25 & 381 & 1639,5 \\
\hline
\end{tabular}

Rata-rata hasil belajar siswa

$$
\begin{aligned}
\bar{X} & =\frac{\Sigma f_{i} x_{i}}{\Sigma f_{i}} \\
& =\frac{1639,5}{25} \\
& =65,58
\end{aligned}
$$

Dalam proses pembelajaran, guru kelas (observer) mengamati peneliti mulai dari awal pelaksanaan penelitian samapai dengan berakhirnya pelaksanaan penelitian. penilaian pada lembar observasi yang telah dipersiapkan sebelumnya. Hasil pengamatan aktivitas guru pada siklus II dapat dilihat pada tabel Dimana Observer memberikan

\begin{tabular}{|c|c|c|}
\hline No & Aspek Yang Diobservasi & Penilaian \\
\hline 1 & Keterampilan membuka pembelajaran & 85 \\
\hline 2 & Menyampaikan materi dan tujuan pembelajaran & 77 \\
\hline 3 & Memberikan penjelasan dengan bahasa yang jelas & 74 \\
\hline 4 & Penguasaan kelas & 75 \\
\hline 5 & $\begin{array}{l}\text { Melaksanakan proses pembelajaran secara sistematik } \\
\text { dengan urutan rpp }\end{array}$ & 75 \\
\hline 6 & $\begin{array}{l}\text { Menguraikan metode pembelajaran sesuai dengan cara } \\
\text { kerja metode Eksperimen dalam kegiatan inti pembelajaran }\end{array}$ & 76 \\
\hline 7 & Memotivasi siswa untuk aktif bertanya & 73 \\
\hline 8 & Penggunaan alokasi waktu sesuai dengan rpp & 70 \\
\hline 9 & Memberikan penilaian & 78 \\
\hline 10 & Mengadakan evaluasi & 77 \\
\hline \multicolumn{2}{|c|}{ Jumlah } & 760 \\
\hline \multicolumn{2}{|c|}{ Persentase } & $76 \%$ \\
\hline \multicolumn{2}{|c|}{ Kategori } & Baik \\
\hline
\end{tabular}
beriku ini :

Tabel Hasil Observasi Aktivitas Guru Siklus II

Dapat digunakan dengan rumus : 


$$
\begin{aligned}
\mathrm{HP} & =\frac{\text { Jumlah Skor Observasi }}{\text { Jumlah Butir Pernyataan }} \\
\mathrm{HP} & =\frac{760}{10} \\
& =76
\end{aligned}
$$

Setiap aspek yang diamati untuk aktivitas guru pada siklus II diperoleh jumlah sebanyak 760 dengan nilai $76 \%$. Kriteria hasil observasi aktivitas guru adalah berkategori Baik. Selama proses pembelajaran guru (observer) juga mengamati aktivitas siswa dalam proses pembelajaran yang sedang berlangsung khususnya pada keaktifan siswa dalam menggunakan metode pembelajaran Eksperimen dengan menggunakan lembar observasi yang telah dipersiapkan sebelumnya. Hasil dari observasi aktivitas siswa pada siklus II dapat dilihat pada tabel berikut ini :

Tabel Hasil Observasi Aktivitas Siswa Siklus II

\begin{tabular}{|l|l|l|}
\hline No & Aspek yang diobservasi & Penilaian \\
\hline 1. & Kesiapan menerima pembelajaran & 4 \\
\hline 2. & Mendengarkan penjelasan guru dengan baik & 3 \\
\hline 3. & Memperhatikan dan mencatat penjelasan guru & 4 \\
\hline 4. & Melakukan Eksperimen & 4 \\
\hline 5. & Keaktifan dalam kerja sama dengan kelompok & 3 \\
\hline 6. & Keaktifan dalam melakukan percobaan & 3 \\
\hline 7. & $\begin{array}{l}\text { Partisipasi dalam mengikuti arahan yang } \\
\text { diberikan oleh guru }\end{array}$ & 4 \\
\hline 8. & Keberanian dalam memberikan pendapat & 4 \\
\hline 9. & Membuat kesimpulan & 4 \\
\hline 10. & Aktif dalam pengerjaan test, tugas,LKS & 4 \\
\hline Jumlah & 37 \\
\hline Persentase & $74 \%$ \\
\hline Kategori & Baik \\
\hline
\end{tabular}

Dapat digunakan rumus :

$$
\begin{aligned}
\text { Nilai } & =\frac{\text { Skor yang diperoleh }}{\text { Jumlah Skor Maksimum }} \times 100 \\
& =\frac{37}{50} \times 100 \\
& =74
\end{aligned}
$$


Hotma Tiolina Siregar : Meningkatkan Hasil ....

Dari setiap aspek yang diamati untuk aktivitas kegiatan siswa pada siklus II diperoleh jumlah sebanyak 37 dengan nilai yang diperoleh mencapai $74 \%$ berdasarkan kriteria penilaian hasil observasi aktivitas siswa pada proses pembelajaran dengan menggunakan metode pembelajaran Eksperimen pada mata pelajaran IPA dengan pokok bahasan Gaya Magnet di kelas V SD Negeri 101823 Bekala Tahun Ajaran 2016/2017 dapat dikategorikan Baik.
Ketuntasan hasil belajar siswa secara individu siklus II. Dari hasil belajar yang diperoleh peneliti dari penelitian tindakan kelas (PTK) di kelas V SD Negeri 101823 Bekala Tahun Ajaran 2016/2017 pada mata pelajaran IPA pada pokok bahasan Gaya Magnet dengan menggunakan metode pembelajaran Eksperimen pada siklus II dapat diperoleh data ketuntasan hasil belajar siswa secara individu yang diuraikan pada tabel berikut ini :

Tabel ketuntasan hasil belajar siswa secara individu siklus II

\begin{tabular}{|l|l|l|l|l|l|l|}
\hline No & Nama & $\begin{array}{l}\text { Skor } \\
\text { Perolehan } \\
\mathbf{( T )}\end{array}$ & $\begin{array}{l}\text { Skor } \\
\text { Total } \\
\mathbf{( T t )}\end{array}$ & $\begin{array}{l}\text { Nilai } \\
\text { Akhir }\end{array}$ & KKM & $\begin{array}{l}\text { Keterangan } \\
\text { (Tuntas/Tidak } \\
\text { Tuntas) }\end{array}$ \\
\hline 1 & Agnes & 65 & 100 & 65 & 70 & Tidak Tuntas \\
\hline 2 & Amelia & 75 & 100 & 75 & 70 & Tuntas \\
\hline 3 & Ayu & 60 & 100 & 60 & 70 & Tidak Tuntas \\
\hline 4 & Brema & 75 & 100 & 75 & 70 & Tuntas \\
\hline 5 & Dewita & 75 & 100 & 75 & 70 & Tuntas \\
\hline 6 & Ibnu & 70 & 100 & 70 & 70 & Tuntas \\
\hline 7 & Intan & 85 & 100 & 85 & 70 & Tuntas \\
\hline 8 & Johan & 70 & 100 & 70 & 70 & Tuntas \\
\hline 9 & Juwanda & 80 & 100 & 80 & 70 & Tuntas \\
\hline 10 & Krisna & 85 & 100 & 85 & 70 & Tuntas \\
\hline 11 & M.Sabri & 90 & 100 & 90 & 70 & Tuntas \\
\hline 12 & M.Yoga & 80 & 100 & 80 & 70 & Tuntas \\
\hline 13 & Marsyanda & 85 & 100 & 85 & 70 & Tuntas \\
\hline 14 & Maymora & 80 & 100 & 80 & 70 & Tuntas \\
\hline 15 & Mikael & 70 & 100 & 70 & 70 & Tuntas \\
\hline 16 & Reza & 90 & 100 & 90 & 70 & Tuntas \\
\hline 17 & Riska & 80 & 100 & 80 & 70 & Tuntas \\
\hline 18 & Rizki & 85 & 100 & 85 & 70 & Tuntas \\
\hline 19 & Sandrina & 50 & 100 & 50 & 70 & Tidak Tuntas \\
\hline 20 & Sarah & 85 & 100 & 85 & 70 & Tuntas \\
\hline 21 & Sari & 85 & 100 & 85 & 70 & Tuntas \\
\hline 22 & Selpia & 95 & 100 & 95 & 70 & Tuntas \\
\hline & & & & & & \\
\hline
\end{tabular}




\begin{tabular}{|l|l|l|l|l|l|l|}
23 & Tegar & 70 & 100 & 70 & 70 & Tuntas \\
\hline 24 & Tika & 80 & 100 & 80 & 70 & Tuntas \\
\hline 25 & Yelen & 95 & 100 & 95 & 70 & Tuntas \\
\hline
\end{tabular}

Dari tabel di atas dapat dilihat bahwa siswa yang tuntas secara individu pada siklus II sebanyak 22 orang siswa tuntas dan 3 orang siswa yang tidak tuntas dari 25 orang siswa pada mata pelajaran IPA di kelas V SD Negeri 101823 Bekala pada pokok bahasan Gaya Magnet dengan menggunakan metode pembelajaran Eksperimen. Dapat dilihat dari hasil yang diperoleh, maka siswa telah tuntas belajarnya dan telah memenuhi kriteria KKM yaitu 70 . Ketuntasan hasil belajar siswa secara klasikal siklus II. Nilai ketuntasan klasikal siklus II dapat dilihat pada tabel berikut ini :

Tabel Ketuntasan Hasil Belajar Siswa Secara Klasiklal Siklus II

\begin{tabular}{|c|c|c|c|}
\hline \multirow[t]{2}{*}{ Ketuntasan } & \multicolumn{2}{|l|}{ Siklus II } & \multirow[t]{2}{*}{ Keterangan } \\
\hline & Jumlah siswa & Persentase & \\
\hline $\begin{array}{l}\text { Siswa yang } \\
\text { tuntas belajar }\end{array}$ & 22 & $88 \%$ & \multirow{3}{*}{$\begin{array}{l}\text { Tuntas secara } \\
\text { Klasikal }\end{array}$} \\
\hline $\begin{array}{l}\text { Siswa yang tidak } \\
\text { tuntas belajar }\end{array}$ & 3 & $12 \%$ & \\
\hline Jumlah Siswa & 25 & $100 \%$ & \\
\hline
\end{tabular}

Untuk menghitung ketuntasan belajar siswa secara klasikal menggunakan rumus sebagai berikut:

$$
\begin{aligned}
\text { Ketuntasan Belajar } & =\frac{\sum \text { siswa yang tuntas belajar }}{\sum \text { siswa }} \times 100 \% \\
& =\frac{22}{25} \times 100 \\
& =88 \% \text { (Siswa yang tuntas) }
\end{aligned}
$$

Sedangkan persentase siswa yang tidak tuntas dapat ditentukan dengan menggunakan rumus sebagai berikut:

$$
\begin{aligned}
\text { Ketuntasan Belajar } & =\frac{\sum \text { siswa yang belum tuntas belajar }}{\sum \text { siswa }} \times 100 \% \\
& =\frac{3}{25} \times 100 \\
& =12 \% \text { (Siswa yang belum tuntas) }
\end{aligned}
$$

Data ketuntasan hasil belajar siswa secara individu diatas dapat 
Hotma Tiolina Siregar : Meningkatkan Hasil ....

dirangkum di dalam tabel distribusi

Perhitungan rata-rata hasil belajar frekuensi untuk mencari nilai rataIPA siklus II

rata menggunakan rumus.

Tabel Distribusi Frekuensi Hasil Belajar IPA Siswa Siklus II

\begin{tabular}{|l|l|l|l|l|}
\hline No & Kelas Interval & \multicolumn{1}{|c|}{$\boldsymbol{f}_{\boldsymbol{i}}$} & \multicolumn{1}{|c|}{$\boldsymbol{x}_{\boldsymbol{i}}$} & \multicolumn{1}{|c|}{$\boldsymbol{f}_{\boldsymbol{i}} \boldsymbol{x}_{\boldsymbol{i}}$} \\
\hline 1. & $50-57$ & 1 & 53,5 & 5,5 \\
\hline 2. & $58-65$ & 2 & 61,5 & 123 \\
\hline 3. & $66-73$ & 4 & 69,5 & 278 \\
\hline 4. & $74-81$ & 8 & 77,5 & 620 \\
\hline 5. & $82-89$ & 6 & 85,5 & 513 \\
\hline 6. & $90-97$ & 4 & 93,5 & 374 \\
\hline Jumlah & 25 & 441 & 1961,5 \\
\hline
\end{tabular}

Rata-rata hasil belajar siswa

$$
\begin{aligned}
\bar{X} & =\frac{\sum f_{i} x_{i}}{\sum f_{i}} \\
& =\frac{1961,5}{25} \\
& =78,46
\end{aligned}
$$

\section{Pembahasan}

\section{Pada}

pelaksanaan pembelajaran aktivitas guru pada siklus I masih berkategori cukup setelah dilakukan perbaikan pada siklus II mengalami peningkatan menjadi berkategori Baik. Dapat dilihat dari perbandingan antara siklus I dan II. Dimana pada siklus I hasil observasi guru 60 dan pada siklus II mengalami peningkatan menjadi 78,2. Untuk melihat perbandingan hasil observasi guru pada siklus I dan II dapat dilihat pada tabel berikut ini : 
SEJ VOLUME 7 NO. 1 JUNI 2017

Tabel Rekapitulasi Hasil Observasi Guru Siklus I Dan II

\begin{tabular}{|l|l|l|l|}
\hline No & Keterangan & Observasi Guru & Keterangan \\
\hline 1 & Siklus I & 63,5 & Cukup \\
\hline 2 & Siklus II & 76 & Baik \\
\hline
\end{tabular}

Siswa pada siklus I 64 masih berkategori cukup dan setelah diadakan perbaikan pada siklus II menjadi 74 maka dari hasil peningkatan observasi siswa pada siklus II dapat dikategorikan Baik. Untuk melihat perbandingan hasil observasi siswa pada siklus I dan II dapat dilihat tabel berikut ini :

Tabel Rekapitulasi Hasil Observasi Siswa Siklus I Dan II

\begin{tabular}{|l|l|c|l|}
\hline No & Keterangan & Observasi siswa & Keterangan \\
\hline 1 & Siklus I & 64 & Cukup \\
\hline 2 & Siklus II & 74 & Baik \\
\hline
\end{tabular}

Untuk

mengetahui

secara individu pada siklus I dan II

peningkatan nilai belajar siswa

dapat dilihat pada tabel berikut ini :

Tabel Rekapitulasi Hasil Belajar Siswa Secara Individu Pada Siklus I Dan II

\begin{tabular}{|l|l|l|l|l|}
\hline No & Nama Siswa & $\begin{array}{l}\text { Nilai } \\
\text { Siklus I }\end{array}$ & $\begin{array}{l}\text { Nilai Siklus } \\
\text { II }\end{array}$ & Keterangan \\
\hline 1 & Agnes & 55 & 65 & $\begin{array}{l}\text { Meningkat } \\
\text { B.tuntas }\end{array}$ \\
\hline 2 & Amelia & 70 & 75 & Meningkat \\
\hline 3 & Ayu & 55 & 60 & $\begin{array}{l}\text { Meningkat } \\
\text { Tuntas }\end{array}$ \\
\hline 4 & Brema & 70 & 75 & Meningkat \\
\hline 5 & Dewita & 70 & 75 & Meningkat \\
\hline
\end{tabular}


Hotma Tiolina Siregar : Meningkatkan Hasil ....

\begin{tabular}{|l|l|l|l|l|}
6 & Ibnu & 60 & 70 & Meningkat \\
\hline 7 & Intan & 75 & 85 & Meningkat \\
\hline 8 & Johan & 50 & 70 & Meningkat \\
\hline 9 & Juwanda & 70 & 80 & Meningkat \\
\hline 10 & Krisna & 85 & 85 & Meningkat \\
\hline 11 & M.Sabri & 70 & 90 & Meningkat \\
\hline 12 & M.Yoga & 75 & 80 & Meningkat \\
\hline 13 & Marsyanda & 45 & 85 & Meningkat \\
\hline 14 & Maymora & 70 & 80 & Meningkat \\
\hline 15 & Mikael & 60 & 70 & Meningkat \\
\hline 16 & Reza & 70 & 90 & Meningkat \\
\hline 17 & Riska & 60 & 80 & Meningkat \\
\hline 18 & Rizki & 85 & 85 & Meningkat \\
\hline & & 40 & & Meningkat \\
19 & Sandrina & & 50 & Tuntas \\
\hline 20 & Sarah & 75 & 85 & Meningkat \\
\hline 21 & Sari & 70 & 85 & Meningkat \\
\hline 22 & Selpia & 85 & 95 & Meningkat \\
\hline 23 & Tegar & 60 & 70 & Meningkat \\
\hline 24 & Tika & 75 & 80 & Meningkat \\
\hline 25 & Yelen & 70 & 95 & Meningkat \\
\hline
\end{tabular}

Dapat dilihat pada tabel di atas, bahwa nilai hasil belajar siswa secara individu meningkat meskipun dalam siklus II masih ada siswa yang tidak tuntas akan tetapi nilainya mengalami peningkatan. Hasil belajar klasikal pada siklus I yaitu 64\% Meningkat pada siklus II yaitu
88\%. Penggunaan metode pembelajaran Eksperimen pada mata pelajaran IPA pokok bahasan Gaya Magnet telah dilaksanakan secara maksimal. Untuk mengetahui peningkatan nilai hasil belajar siswa secara klasikal pada siklus I dan II dapat dilihat pada tabel berikut ini :

Tabel Rekapitulasi Hasil Belajar Siswa Secara Klasikal Siklus I Dan II

\begin{tabular}{|l|l|l|l|l|}
\hline No & Tes & $\begin{array}{c}\text { Jumlah Siswa Yang } \\
\text { Tuntas }\end{array}$ & Persentase & Keterangan \\
\cline { 1 - 4 } 1 & Siklus I & 16 & $64 \%$ & KMeningkat \\
\hline 2 & Siklus II & 22 & $88 \%$ & \\
\hline
\end{tabular}

Dari tabel di atas dapat dilihat adanya peningkatan hasil belajar siswa secara klasikal dari siklus I sampai II pada pelajaran IPA pokok bahasan Gaya Magnet dan hasil belajarnya di kelas V SD Negeri 
101823 Bekala Tahun Ajaran 2016/2017 telah mencapai ketuntasan klasikal yaitu : $\geq 85 \%$.

Nilai rata-rata pada siklus I yaitu 65,58 meningkat pada siklus II yaitu 78,46 . Bahwa dengan menggunakan metode pembelajaran Eksperimen pada mata pelajaran IPA dengan pokok bahasan Gaya Magnet yang dilaksanakan peneliti dapat meningkatkan hasil belajar siswa. Berdasarkan target ketuntasan belajar yaitu 70 dan hasil belajar secara klasikal $\geq 85 \%$ sudah tercapai. Dan untuk mengetahui adanya peningkatan nilai rata-rata hasil belajar siswa pada siklus I dan II dapat dilihat pada tabel berikut ini :

Tabel Nilai Rata-rata Hasil Belajar Siswa pada siklus I dan II

\begin{tabular}{|l|l|l|l|}
\hline No & Tes & $\begin{array}{c}\text { Nilai Rata- } \\
\text { rata }\end{array}$ & Keterangan \\
\hline 1 & Siklus I & 65,58 & Meningkat \\
\cline { 1 - 3 } 2 & Siklus II & 78,46 & \\
\hline
\end{tabular}

Berdasarkan uraian diatas dapat dibuktikan bahwa "Dengan menggunakan metode pembelajaran Eksperimen dapat meningkatkan hasil belajar siswa pada mata pelajaran IPA dengan pokok bahasan Gaya Magnet di kelas V SD Negeri 101823 Bekala Tahun Ajaran 2016/2017" dapat diterima

\section{SIMPULAN}

a. Pelaksanaan pembelajaran menggunakan metode Eksperimen pada mata pelajaran IPA pokok bahasan Gaya Magnet di kelas V SD Negeri 101823 Bekala Tahun Ajaran 2016/2017 berkategori baik.

b. Hasil Belajar Siswa Meningkat Setelah Menggunakan metode Eksperimen pada mata Pelajaran
IPA pokok bahasan Gaya Magnet di Kelas V SD Negeri 101823

Bekala Tahun Ajaran 2016/2017.

\section{DAFTAR RUJUKAN}

Anas, Salahudin. 2015. Penelitian Tindakan Kelas. Bandung: Pustaka Setia.

Aqip, Zainal dkk. 2011. Penelitian Tindakan Kelas. Bandung: Yrama Widya

Amalia Sapriati, dkk. 2013. Pembelajaran IPA di SD. Tanggerang Selatan: Universitas Terbuka.

Arikunto. Suharsini. 2014. Penelitian Tindakan Kelas. Jakarta: PT Bumi Aksara.

Djamarah, Syaiful Bahri dan Aswan Zain. 2013. Strategi Belajar 
Hotma Tiolina Siregar : Meningkatkan Hasil ....

Mengajar. Jakarta: Rineka Cipta.

Hamdani. 2011. Strategi Belajar Mengajar. Bandung: Pustaka Setia.

Hernawan. 2013. Belajar dan Pembelajaran SD. Bandung: UPI Press.

Haryanto. 2014. Sains. Jakarta: Pustaka Setia

Irene. Dkk. 2015. Ilmu Pengetahuan Alam. Jakarta: Esps.

Istarani dan Intan Pulungan. 2015. Ensiklopedi Pendidikan Jilid 1. Medan: CV Iscom Medan.

Istarani. 2012. Kumpulan 39 Metode Pembelajaran. Medan: CV Iscom Medan.

Jihad Asep, Abdul Haris. 2012. Evaluasi Pembelajaran. Yogyakarta: Multi Pressindo.

Masnur, $\quad$ Muslich. 2014. Melaksanakan PTK itu Mudah. Jakarta: PT Bumi Aksara.
Oemar, Hamalik. 2014. Proses Belajar Mengajar. Jakarta: PT Bumi Aksara.

Rostiyah, N.K. 2012. Strategi Belajar Mengajar. Jakarta: Rineka Cipta.

Slameto. 2013. Belajar dan FaktorFaktor yang Mempengaruhi. Jakarta: Rineka Cipta.

Sahertian, A. Piet. 2013. Evaluasi Pembelajaran. Jakarta: Rineka Cipta.

Susanto Ahmad. 2014. Teori Belajar \& Pembelajaran di Sekolah Dasar. Jakarta: Prenada media Group.

Sudjana, N. 2013. Dasar-Dasar Proses Belajar Mengajar. Bandung: Sinar Baru Algensindo.

Trianto. 2016. Penelitian Tindakan Kelas. Jakarta: Bumi Aksara. 